on each of these topies, it is not easy to see what useful information could be crammed into chapters of five to ten pages in an elementary textbook. Perhaps it might have been better to limit its scope. Apart from this shortcoming the book provides a readable and up to date introductory text.

An interesting feature of Butler's style is that he is meticulous in mentioning the names of the scientists associated with each discovery. The book is well illustrated with clear line drawings and plates of moderate quality. It has a well-selected bibliography for each chapter.

John PaUt

\section{SCAVENGING CELLS}

\section{The Macrophage}

By Nancy N. Pearsall and Russell Weiser. Pp. $x+204$. (Lea and Febiger: Philadelphia, 1970. Distributed in Great Britain by Henry Kimpton, London.) $76 s$.

I $\mathrm{T}$ is impossible in a short review to do justico, critically and otherwise, to this little book in which the authors have compressed an enormous amount of information, in fact, more than it can hold, and under chapter hoadings which frequently indicate overlap.

Although the book is called The Macrophage, great emphasis is laid on the diversity of macrophage populations and the great inter- and intra-species differences that exist among these populations morphologically, biochemically and functionally. Strangely, the fact that cultured fowl macrophages proliferate actively in homo. logous serum is not mentioned; yet the special macrophage growth factors necessary for the proliferation of macrophages ("mammalian" should have been added) receive due consideration.

In the first half of the book, the structure of macrophage (poorly illustrated by only a fow olectron micro graphs), phylogenetic and ontogenetic aspects, sources and lifespan, cellular interrelationships (incidentally, the claim that lymphocytes transform into macrophages only in the presence of polymorphs still awaits confirmation), metabolic activities, phagocytosis and functions (sic!) of macrophages are reviewed and discussed. The chapter on metabolism contains a useful, comprohensive table on enzymes found in macrophages.

The second half of the book is concerned with the role of macrophages in immunological situations and is addressed more to the expert in this field than to the uninitiated reader. It deals with contributions of macrophages to the antibody response, with antibodies cytophilic for macrophages, with delayed sensitivity and antitissue and antimicrobial cellular immunity with special discussions of tuberculosis, leprosy, the Listeria and the Salmonella systems. There is no doubt that macrophages act as scavengers, trapping, processing and storing antigenic material, but whether they are specific effector cells remains still an open question; and it is perhaps significant that one of the authors' concluding sentences reads: "Overall, lymphocytes and macrophages cocperate in an effective cellular immune response".

The great merit of the book lies in the accumulation of numerous data on the subject which have appeared in recent years in widely scattered journals. Of the 699 references quoted, only 160 were published before 1960 ; this makes the work invaluable as a reference book. One can say, it is up to date as far as this is possible these days. Some of the papers quoted are reviewed in detail; others are summarized in such a condensed form that this does not give sufficient information or sometimes even a misleading or an inaccurate one; and any reader of this monograph would be well advised to go back to the original reference, because this is, after all, one of the aims of this book.

\section{BEFORE THE ANTIBIOTICS ERA}

A History of Medical Bacteriology and Immunology By W. D. Foster. Pp. xi +232. (Heinemann (Medical): London, July 1970.) 40s.

THERE is a wide variety of general books on the history of medicine but, on the whole, the history of its special areas is less well served. Thus this book is only the third history of bacteriology in English to appear and the need for it has been evident for some time because neither of its predecessors, Bulloch's History of Bacteriology (1938) and Ford's Bacteriology (1939), is entirely adequate. Bulloch, for example, dealt at great length with the earlier periods, finishing at 1900, and did not cover the medical aspects of the subject fully.

Dr Foster is ideally suited for the task of providing a competitor for Bulloch and Ford because he has already published excellent accounts of the history of clinical pathology and of parasitology. He begins his book with a brief introduction to the germ theory of disease which was established in the $1870 \mathrm{~s}$, and then discusses in detail the contributions of Pasteur and Koch to its foundation. There is a good chapter on the discovery of the more important human pathogenic bacteria, a vital aspect of the subject but hardly mentioned by Bulloch. As his title indicates, Foster includes the history of immunology, first its scientific basis and then its practical application to medicine; in this regard he might have mentioned $A$ History of Immunization by H. J. Parrish (1965). The last two chapters comprise an excellent account of the principal developments in bactoriology during the early twentieth contury, and in the chemotherapy of bacterial disease. Medical students should be oncouraged to peruse these carefully in order to counter the commonly held view that specific therapy commenced in the 1930 s and 1940 s with the introduction of sulpha drugs and antibiotics. One useful secondary source Foster omits to cite hero is The Impact of the Antibiotics on Medicine and Society (edited by I. Goldston, New York, 1958).

A criticism of this book could be levelled at the introductory chapter dealing with events before the germ theory. From it important men such as Fracastoro, who gave the first "modern" interpretation of contagion, Semmelweis and Oliver Wendell Holmes of puerperal fever fame, and others of merit have been excluded. Admittedly Bulloch perhaps discussed early concepts in too great detail, but Foster would seem to have gone to the other extreme. It can be argued, however, that, given a limited amount of space, more should be allocated to the most modern rather than to the earlier period. This may be less acceptable to the historian but it certainly is an advantage to students and practitioners who prefer to know of the immediate rather than the distant past.

Foster is to be congratulated on his achievement, for he has produced a history of bacteriology which is orientated adequately to medicine and which provides for the first time an account of the most recent history of the subject, up to 1938, a convenient date because it marks the eve of the antibiotics era, as well as the appearance of the previous histories by Bulloch and Ford. Moreover, he gives evidence throughout of appreciating the meaning and methodology of history. His book can be warmly recom. mended and parts of it should be required reading for medical students.

EDWIN Clarke

\section{TIPS FOR MICE BREEDERS}

Methods in Experimental Embryology of the Mouse

By Keen A. Rafferty, jun. Pp. xi +94. (Johns Hopkins: Baltimore and London, August 1970.) 81s.

WALTER HeaPe, the father of experimental embryology in mammals, wrote: "On the 27th April, 1890, two ova were 